\title{
Improved downstream process for the production of plasmid DNA for gene therapy
}

\author{
Jochen Urthaler ${ }^{\bowtie}$, Wolfgang Buchinger and Roman Necina \\ Boehringer Ingelheim Austria GmbH, Vienna, Austria; \\ 凶e-mail: jochen.urthaler@vie.boehringer-ingelheim.com
}

Received: 15 March, 2005; revised: 05 July, 2005; accpted: 03 August, 2005

available on-line 15 September, 2005

\begin{abstract}
Gene therapy and genetic vaccines promise to revolutionize the treatment of inherited and acquired diseases. Since viral vectors are generally associated with numerous disadvantages when applied to humans, the administration of naked DNA, or DNA packed into lipo- or polyplexes emerge as viable alternatives. To satisfy the increasing demand for pharmaceutical grade plasmids we developed a novel economic downstream process which overcomes the bottlenecks of common lab-scale techniques and meets all regulatory requirements. After cell lysis by an inhouse developed gentle, automated continuous system the sequence of hydrophobic interaction, anion exchange and size exclusion chromatography guarantees the separation of impurities as well as undesired plasmid isoforms. After the consecutive chromatography steps, adjustment of concentration and final filtration are carried out. The final process was proven to be generally applicable and can be used from early clinical phases to market-supply. It is scaleable and free of animal-derived substances, detergents (except lysis) and organic solvents. The process delivers high-purity plasmid DNA of homogeneities up to $98 \%$ supercoiled form at a high yield in any desired final buffer.
\end{abstract}

Keywords: plasmid DNA, alkaline lysis, production, purification, chromatography, gene- therapy

For the production of pharmaceutical-grade plasmid DNA (pDNA) at an industrial scale three main requirements have to be met. First, the drug substance produced must be of highest quality, free from contaminating bacterial components. Second, the process has to produce a cost-effective yield per volume of culture broth. Last, the whole process must be compliant to regulatory guidelines.

Thereby the physico-chemical properties of pDNA, which are significantly different to those of proteins, have a strong impact on the technical and quality related issues (Table 1). The charge of polynucleotides is highly negative under physiological conditions and due to their size and shape they are more sensitive to shear forces (Levy et al., 1999a; 1999b; 2000a; 2000b). A typical plasmid with a size of 3 to 20 kilo base pairs appears in different topological isoforms. The supercoiled (sc) or covalently closed circular (ccc) form (Sinden \& Alkek, 1994) is considered as most appropriate for therapeutic applications and is therefore the desired form. The other topological pDNA forms are derived from the ccc form by either single strand nick (open circular or oc) or double strand nick (linear). Conjugation, in turn, leads to di- and oligo-/multimeric pDNA forms, called concatemers and catenanes (Kreuzer \& Cozzarelli, 1980; Martin, 1996; Summers, 1996). The homogeneity, expressed as percentage of the ccc form, should be higher than 90\% (US FDA, 1996a; 1996b; Marquet et al., 1997) and is the most important parameter, beside the purity, to determine the quality of the final pDNA product (US FDA, 1996c). A minimized content of other host-related impurities such as gDNA, RNA, proteins and endotoxins is obligatory as well (Jansen \& Petterson, 1993, Wicks et al., 1995; Sofer \& Hagel, 1997a; Middaugh et al., 1998; Strick et al., 1998; US FDA, 1998; Prazeres et al., 1999; Schleef et al., 1999; Weir, 1999; Levy et al., 2000b).

^Paper was presented at the International Review Conference on Biotechnology, Vienna, Austria, November 2004. Abbreviations: AIEC, anion-exchange chromatography; ccc, covalently closed circular; CIP, cleaned in place; $\mathrm{cV}$, column valume; gDNA, genomic DNA; HIC, hydrophobic interaction chromatography; oc, open circular; pDNA, plasmid DNA; sc, supercoiled; SEC, size-exclusion chroamtography; SIP, steamed in place. 
Table 1. Comparison of the physico-chemical properties of proteins and plasmids.

The larger size of plasmids strongly influences all the other properties such as diffusion coefficient, viscosity and shear force sensitivity.

\begin{tabular}{lll}
\hline Characteristic & Biomolecule & \\
\cline { 2 - 3 } & Protein & Plasmid \\
\hline Building blocks & amino acids & nucleotides \\
Molecular mass $(\mathrm{kDa})$ & $10^{3}-10^{5}$ & $10^{6}-10^{7}$ \\
Stokes radius & $<5 \mathrm{~nm}$ & $100>300 \mathrm{~nm}$ \\
Charge & depending on & negative \\
& $\mathrm{pI} / \mathrm{pH}$ & \\
Diffusion coefficient & medium-high & low \\
Viscosity & low & high \\
Shear-force sensitivity & low & high \\
\hline
\end{tabular}

In general, a process for producing pDNA therapeutics follows the steps of fermentation, cell disintegration and purification. Yield, productivity, cost of goods and validation have a major impact on the process economy and the overall performance. For fermentation at present Escherichia coli is the most commonly used production host. Key parameters of the fermentation process are cell density and plasmid copy number as well as homogeneity and yield (total/specific), which are strongly influenced by the host strain, the fermentation mode, the medium-composition and the harvesting point (Kreuzer \& Cozzarelli, 1980). For the purification chroma- tography supports providing a high pDNA capacity and high flow-rates, resulting in a high productivity, are required (Sofer \& Hagel, 1997b). A step yield greater than $80 \%$ is obligatory for an economic process. Generally, simple unit operations and the avoidance of critical reagents such as animal-derived compounds (e.g., enzymes), detergents and organic solvents significantly reduce the effort for validation and for precautions regarding patient and operator safety.

Downstream processing of pDNA starts with the disintegration of cells to release the plasmid. Since high-pressure homogenization due to the shear force sensitivity of polynucleotides (Carlson et al., 1995) is not applicable, and enzymatic disintegration (Asenjo \& Andrews, 1990) are economically and regulatorily unfavorable, chemical lysis (Foster, 1992) is the method of choice for industrial-scale production of pDNA. Usually, the disintegration of bacterial cells is therefore performed by alkaline lysis, first described by Birnboim and Doly (1979).

After recovering a clarified lysate one or usually more purification steps take place. Table 2 gives a rough overview of currently published processes for pDNA purification. Precipitation and extraction of pDNA by organic solvents, ultrafiltration, and predominantly liquid chromatographic techniques are most widely used for this purpose. Most of the available processes for pDNA purification are time-

Table 2. Comparison of different published techniques for capture, purification and polishing of pDNA.

In the majority of the processes cell disintegration is carried out by (modified) alkaline lysis.

\begin{tabular}{|c|c|c|c|c|}
\hline Scale & Capture Step & Purification & Polishing & Reference \\
\hline Lab & Aqueous two phase extraction & HIC & - & Ribeiro et al., 2002 \\
\hline $\mathrm{Lab}$ & Anion-exchange membranes & & & Endres et al., 2003 \\
\hline 151 & Anion-exchange membranes & & & Zhang et al., 2003 \\
\hline Lab & AIEC & - & - & Prazeres et al., 1998 \\
\hline $\mathrm{Lab}$ & Triplex-Affinity-Interaction & - & - & Schluep \& Cooney, 1998 \\
\hline 31 & AIEC-Expanded bed adsorption & & - & Ferreira et al., 2000 \\
\hline $\mathrm{Lab}$ & AIEC-Expanded bed adsorption a & nd Ultradiafiltration & SEC & Varley et al., 1999 \\
\hline 101 & Ultradiafiltration & & AIEC & Eon-Duval \& Burke, 2004 \\
\hline $\mathrm{Lab}$ & IMAC & - & - & Murphy et al., 2003 \\
\hline $\mathrm{Lab}$ & SEC & - & - & Ferreira et al., 1997 \\
\hline $\mathrm{Lab}$ & Ammonium-sulfate precipitation & and HIC & - & Diogo et al., 2000 \\
\hline Lab & $\begin{array}{l}\text { Continuous annular chromato- } \\
\text { graphy with hydroxyapatite }\end{array}$ & - & - & Giovannini \& Freitag, 2002 \\
\hline Lab & $\begin{array}{l}\text { Flow-through-AIEC (uncharged } \\
\text { surface) }\end{array}$ & AIEC & - & Gustavsson et al., 2004 \\
\hline Production & $\begin{array}{l}\text { Ultradiafiltration and ammo- } \\
\text { nium-sulfate precipitation }\end{array}$ & $\mathrm{RPC}$ & AIEC & McNeilly \& David, 2001* \\
\hline Production & CTAB precipitation & $\begin{array}{l}\text { Flow-through chromatogra- } \\
\text { phy (potassium silicate) }\end{array}$ & Alcohol precip. & Lander et al., 2001* \\
\hline Production & PEG precipitation & AIEX & SEC & Horn et al., 1998* \\
\hline Production & PEG precipitation & SEC & - & Marquet et al., 1995* \\
\hline Production & $\begin{array}{l}\text { Binding on carrier (e.g., glass- } \\
\text {-membrane) }\end{array}$ & $\begin{array}{l}\text { Filtration and desorption } \\
\text { from carrier }\end{array}$ & - & Hayashizaki, 1997* \\
\hline
\end{tabular}

*Patent publications; HIC, hydrophobic interaction chromatography; AIEC, anion exchange chromatography; SEC, size exclusion chromatography; IMAC, immobilized metal affinity chromatography; RPC, reversed phase chromatography; PEG, polyethylene glycol. 
consuming and not scalable. Furthermore, due to the application of materials that are not certified for application in humans or due to the application of enzymes of avian or bovine origin and of toxic reagents such as phenol, $\mathrm{CsCl}, \mathrm{CsBr}$, etc., these processes do not meet the appropriate guidelines of the regulatory authorities (Miller et al., 1997; Ferreira et al., 2000; Shamlou, 2003; Prather et al., 2003; Eon-Duval \& Burke, 2004).

Chromatography is considered as the method with highest resolution, therefore being essential for producing pDNA suited for therapeutic applications. The most commonly used techniques are anion exchange (AIEC) (Eon-Duval \& Burke, 2004), hydrophobic interaction (HIC) (Diogo et al., 2000) and size-exclusion chromatography (SEC) (Horn et al., 1995). It has to be considered that the large pDNA molecules adsorb only at the beads' outer surface of particulate supports (Mao et al., 1991; 1993; Prazeres et al., 1999; Eon-Duval, 2003; Shamlou, 2003; Zöchling et al., 2004). Consequently capacities are usually on the order of hundreds of micrograms of plasmid per milliliter of chromatographic support, compared to $200 \mathrm{mg} / \mathrm{ml}$ reported for proteins (Shamlou, 2003). Apart from impurities, the supports must also be suited for the separation of the undesired pDNA isoforms. Summarized, efficient pDNA purification requires a fast, reliable and affordable high-resolution downstream process under mild conditions.

Technologically advanced alternatives to porous particles are monoliths, which are continuous beds consisting of a single piece of a highly porous solid material (Tennikova \& Svec, 1993; Svec \& Frechet, 1995). Since the liquid moves through the pores of these supports by convective flow, mass transport is not diffusion-limited and therefore enhanced. In addition, the majority of binding sites are accessible to pDNA, resulting in an increased capacity. It has been previously shown, also by our own work (Necina et al., 2003; Urthaler et al., 2005), that polymethacrylate-based short monolithic columns (Strancar et al., 2002), distributed under the trade name CIM (Convective Interaction Media) (Podgornik et al., 1999) can be used for pDNA purification (Giovannini et al., 1998; Strancar et al., 2002; Bencina et al., 2004; Branovic et al., 2004; Zöchling et al., 2004).

In this paper we describe our novel purification process for pDNA. The development resulted in a generic and scaleable industrial process, which is routinely used in the scale of 200L up to 4000L fermentations, proven with various plasmids of 3-10 kbp in size (Fig. 1). The process consists of a gentle, automated and continuous lysis and clarification procedure (Urthaler et al., 2004) and three subsequent chromatography steps, based on different principles, as key steps of the purification. All critical components of many existing pDNA production processes such as antibiotics, enzymes, detergents

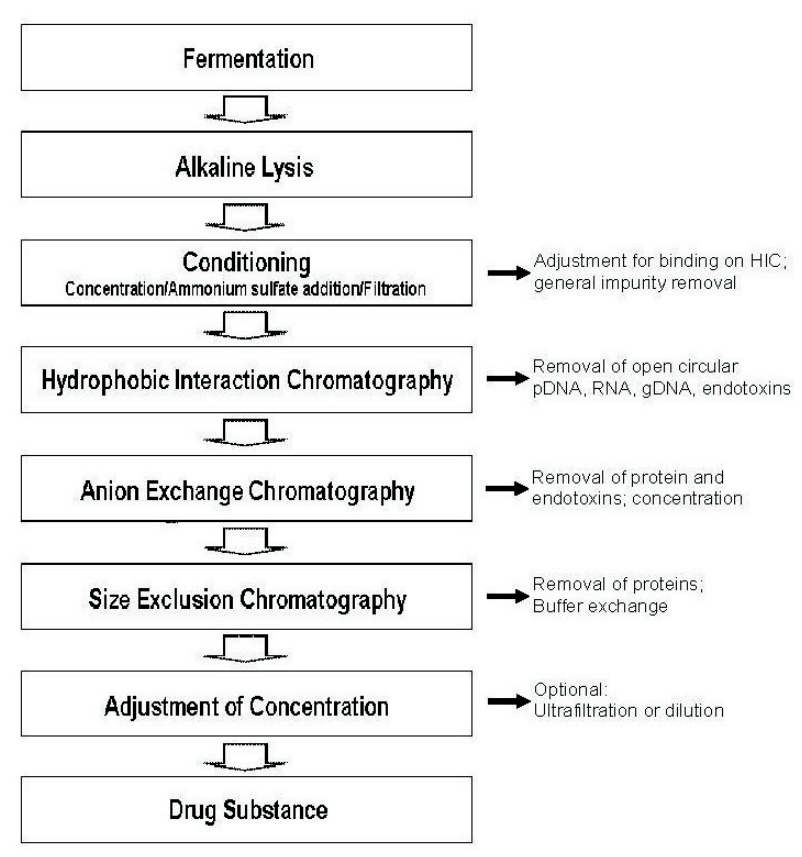

Figure 1. Process steps of the developed pDNA production process and their function.

(except SDS during lysis) and organic solvents are avoided. Process-control is performed by novel high resolution analytical methods guaranteeing highest possible quality standards. The process fulfills all regulatory requirements and delivers pharmaceutical-grade pDNA, which is up to $98 \%$ in the supercoiled form. The final genomic DNA content is lower than $10 \mu \mathrm{g} / \mathrm{mg}$ plasmid DNA, RNA is not detectable by agarose gel electrophoresis, the protein content is lower than $1 \mu \mathrm{g} / \mathrm{mg}$ plasmid DNA and the endotoxin content lower than $0.1 \mathrm{EU} / \mathrm{mg}$ plasmid DNA at the industrial scale. An average overall yield of $50 \%$ in the desired final buffer was obtained.

\section{MATERIALS AND METHODS}

\section{Materials}

For the chromatography steps Toyopearl Butyl $650 \mathrm{M}$ was purchased from Tosoh (Stuttgart, Germany). The CIM DEAE supports were provided by BIA Separations (Ljubljana, Slovenia) and Sepharose 6 FF by Amersham Biosciences (Uppsala, Sweden). Filters for the conditioning step (Kleenpack HDC II) were provided by Pall (New York, USA) and for final 0.22 $\mu \mathrm{m}$ filtration (Millipack) by Millipore (Billerica, MA, USA). For ultrafiltration hollow fiber cartridges from Amersham Biosciences were used for lysate concentration and Pellicon casettes from Millipore for the final adjustment of the concentration.

HPLC analysis was carried out with DNANPR columns (id: $4.6 \mathrm{~mm}$, length: $75 \mathrm{~mm}$, particle 
size: $2.5 \mu \mathrm{m}$ ) purchased from Tosoh (Stuttgart, Germany).

Ammonium sulfate was purchased from JT Baker (Phillipsburg, NJ, USA) and SDS from SigmaAldrich (St. Louis, MO, USA). All other chemicals were purchased from Merck KGaA (Darmstadt, Germany).

The plasmid pRZ-hMCP1 (4.9 kbp; host: E. coli K12 JM108, ATCC No. 47107) and four other plasmids (hosts: JM108 and DH5- $\alpha$ ) in the size range of 3 to $10 \mathrm{kbp}$ were used as model plasmids. E. coli biomass containing pDNA was produced in-house. Fermentations were carried out either in a batch or a fed batch mode, currently yielding up to $1 \mathrm{~g}$ pDNA/1 fermentation broth in a continuous stirred tank reactor according to a proprietary protocol.

\section{Instrumentation}

For the cell disintegration and clarification a proprietary system, built in-house was used. For the chromatography steps QuickScale columns from Millipore were used for the particulate supports. In the case of the monolithic support prepacked $800-\mathrm{ml}$ radial flow CIM tube monolithic columns (BIA Separations) were applied. The runs were conducted on a K-Prime 400 II system with software CCP Version 5.00 (Millipore). Ultradiafiltration steps were carried out on in-house assembled systems. For the flat membranes the Centrasette (Pall) was used as a cassette holder. Membrane-filtration steps were carried out by peristaltic pumps (Watson Marlow).

Analytical HPLC was carried out on an Agilent 1100 system (Agilent Technologies, Palo Alto, CA, USA).

\section{Methods}

Analytics. For the quantification and qualification of pDNA an in-house-developed anionexchange HPLC protocol was used as a standard method. Since the established method enables one to distinguish between the different topological pDNA isoforms the homogeneity can be determined beside the pDNA concentration.

The applied flow rate for the DNA-NPR column was $1 \mathrm{ml} / \mathrm{min}$ for all steps. As equilibration buffer $20 \mathrm{mM}$ Tris/ $\mathrm{HCl}$ at $\mathrm{pH} 9.0$ was applied. Elution was achieved by applying a linear gradient of $50-75 \%$ elution buffer $(20 \mathrm{mM}$ Tris/ $\mathrm{HCl}, 1 \mathrm{M} \mathrm{NaCl}$, $\mathrm{pH} 9.0$ ) within $5 \mathrm{~min}$. Detection was carried out at a wavelength of $260 \mathrm{~nm}$ (reference: 360/100).

This HPLC method was used for fraction and pool analysis and to determine the yield and recovery of each process step. Since the exact elution-time of the different pDNA isoforms depends on the size of the plasmid, internal standards were used for peak identification. During standard in-process-control external standards were used.

Genomic DNA was determined by Southern blotting or qPCR, and RNA by agarose gel electrophoresis. For the detection of residual protein the bicinchoninic acid (BCA) assay was used. Endotoxins were analyzed by a LAL-gel clotting assay according to USP.

Cell disintegration/alkaline lysis. The E. coli cells were disintegrated by a modified alkaline lysis method initially described by Birnboim and Doly (1979) (see also: Birnboim, 1983), utilizing a novel proprietary automated system (Urthaler et al., 2004). First, the pDNA-containing wet cell paste was resuspended in resuspension buffer $(0.05 \mathrm{M}$ Tris $/ \mathrm{HCl}$, $0.01 \mathrm{M}$ EDTA, $\mathrm{pH} 8$ ) by stirring the mixture at room temperature until a homogenous suspension was obtained. Afterwards, lysis by $0.2 \mathrm{M} \mathrm{NaOH}$ and $1 \%$ SDS, neutralization by $3 \mathrm{M}$ potassium acetate at $\mathrm{pH}$ 5.5 and clarification took place continuously in the respective devices of the system. Collected clarified lysate was further processed. For comparison, reference samples were produced by manual lysis of small aliquots of the resuspended cells.

\section{Purification}

The clarified lysate was conditioned by a three-step procedure. First the lysate was concentrated by hollow-fiber ultrafiltration by a factor of 5-10. Afterwards, a $4 \mathrm{M}$ ammonium sulfate stock solution was added to adjust the solution to achieve binding on the subsequent HIC column. Finally the precipitate built during ammonium sulfate addition was removed by filtration. The conditioned lysate was loaded on the HIC column at a linear velocity of 120

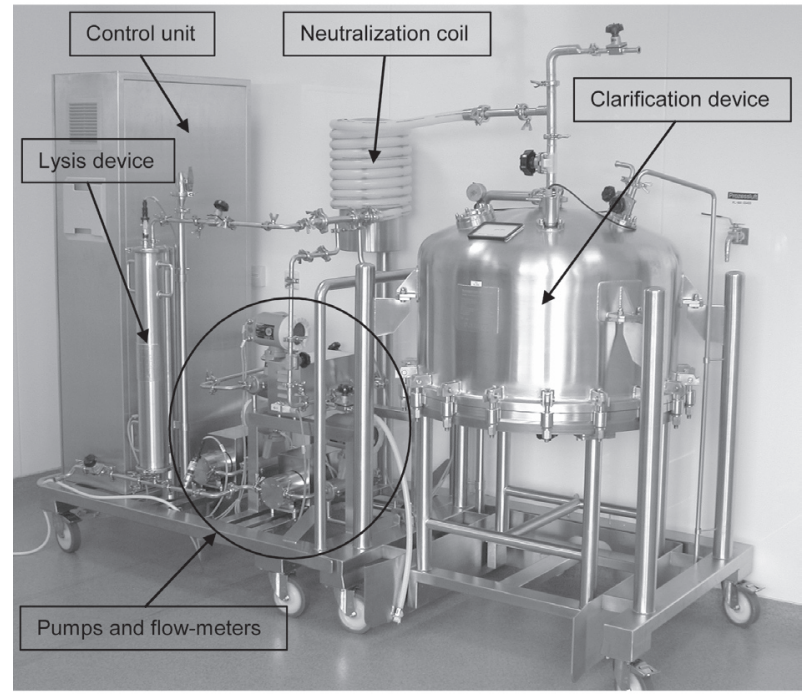

Figure 2. Automated lysis system.

System for industrial scale lysis, neutralization and clarification used for routine production of pharamaceuticalgrade $\mathrm{pDNA}$. 
$\mathrm{cm} / \mathrm{h}$ for binding. Elution at $75 \mathrm{~cm} / \mathrm{h}$ was achieved by applying an optimized linear gradient. The buffers used contained $0.1 \mathrm{M}$ Tris, $0.01 \mathrm{M}$ EDTA with and without $2.8 \mathrm{M}$ ammonium sulfate at $\mathrm{pH}$ 7. The ccc-pDNA containing fractions were pooled and directly loaded on the AIEC column, which was previously equilibrated with a buffer of same composition like that used for elution from the HIC column, containing $0.3 \mathrm{M} \mathrm{NaCl}$. Loading was performed at 2 column volumes $(\mathrm{cv}) / \mathrm{min}$. Elution of ccc-pDNA was carried out by a gradient step to $40 \%$ of elution buffer containing $1.5 \mathrm{M} \mathrm{NaCl}$ at a flow-rate of $0.5-1$ $\mathrm{cv} / \mathrm{min}$. The collected pDNA solution was further processed directly at $60 \mathrm{~cm} / \mathrm{h}$ by the SEC column, which was equilibrated with formulation buffer. To adjust the desired final concentration the volume of the SEC pool was reduced by simple ultrafiltration. At the end of the process $0.22 \mu \mathrm{m}$ filtration of the final pDNA solution was conducted.

\section{RESULTS}

Our development for the cell disintegration step of E. coli cells for pDNA production resulted in an automated modified alkaline lysis method. The subsequent clarification step is directly linked. The developed devices provide a gentle and continuous cell lysis and (semi-) continuous separation of the flocks consisting of precipitated impurities and detergent. The system for GMP production (Fig. 2) consists of two skids including a central controlunit. The containers and tubings are made of highquality stainless steel (316L) and plastics suited for pharmaceutical production in a sanitary design. They can be cleaned in place (CIP) and steamed in place (SIP).

The results of the optimized process step obtained in routine production without the use of enzymes are similar to the gentle, manual reference lysis. As an example Fig. 3 shows the relevant analytical chromatograms obtained with a $6.9 \mathrm{kbp}$ plasmid. The elution profile and the peak pattern were similar. Beside the plasmid size, the large amount of impurities present in the lysate contributes to a later elution of ccc-pDNA from the analytical column compared to, e.g., the HIC pool of the $4.9 \mathrm{kbp}$ plasmid shown in Fig. 4. The yield of the automated lysis was in the range of $80-100 \%$ compared to the manual procedure. Assuming that the reference method is quantitative it can be concluded that all cells were disintegrated by the automated system and the majority of pDNA recovered. The purity was comparable as well. Furthermore, the homogeneity was in the same range of about $90 \%$. Therefore it can be summarized that the automated procedure is gentle and applies only low shear forces without degradation of pDNA.
In contrast to other protocols, which start with AIEC, HIC was chosen as the capture step due to the results of a previous comparison study. Due to the initially present salt concentration in the lysate the amount of ammonium sulfate needed to bind pDNA on the HIC support was lower compared to the use after AIEC. In most of the experiments with AIEC as a capture step the yield and the recovery were lower. The combination of the conditioning and the HIC step is advantageous since most of the impurities, also potentially contributing to pDNA degradation, are already separated at an early process stage.

By the lysate concentration step the process time until end of loading the first chromatography column could be reduced by at least $50 \%$. During the ammonium sulfate addition various initially present impurities precipitate and can be removed by the subsequent filtration.

The outstanding resolution of the optimized HIC-capture step at an industrial scale is shown by the preparative chromatogram and the corresponding analytical HPLC chromatograms in Fig. 4. All peaks are baseline separated. In this example the smaller pRZ-hMCP1 plasmid of $4.9 \mathrm{kbp}$ was used. Therefore the HPLC retention time was shorter com-
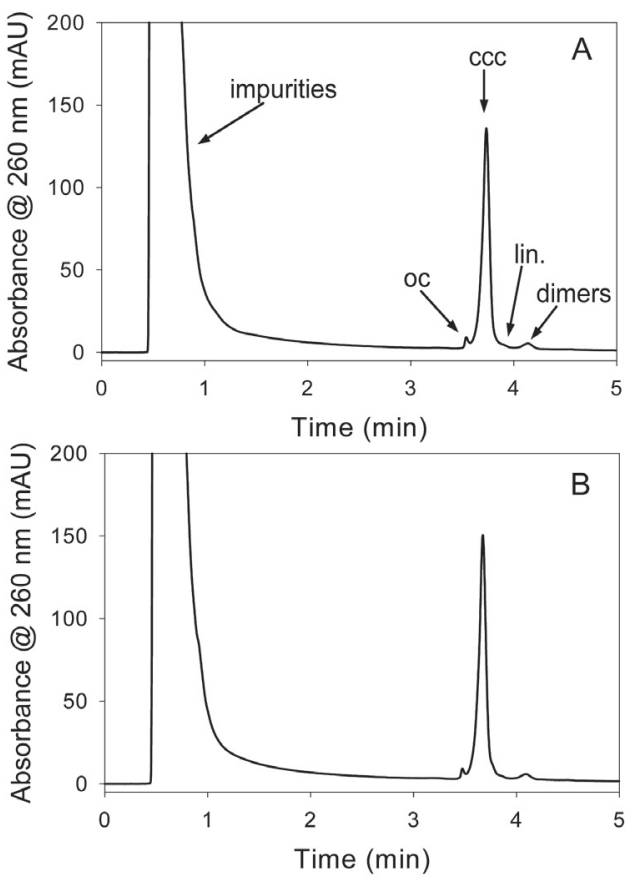

Figure 3. Performance of the continuous lysis and clarification step.

Lysate (6.9 kbp-plasmid) of the novel continuous automated system (analytical HPLC chromatogram, A) versus reference lysate (analytical HPLC chromatogram, B): both treated with RNase for analysis. Alkaline lysis was done by continuous mixing of resuspended cells with lysis buffer (contains $\mathrm{NaOH}$ and SDS) and subsequent neutralization by potassium acetate buffer for the large scale system. For the reference lysate the same buffers were used but lysis was carried out discontinuously, at a small scale by hand. 
pared to the 6.9-kbp plasmid shown in the lysis example (Fig. 3). The first peak contains oc-pDNA and some impurities, while the second peak is the main product peak. It contains pDNA of a homogeneity higher than 95\% ccc form and a strongly reduced impurity content. This fraction (b) was further processed by the intermediate step. RNA and more strongly bound impurities elute with the third peak. The last peak is caused by regeneration with $\mathrm{NaOH}$.

Beside the obvious reduction of RNA, the HIC step is characterized by excellent properties for the removal of residual gDNA, proteins and especially endotoxins. Usually yields greater than $80 \%$ were observed for this capture step.

Since the intermediate step should also serve as a concentration step, supports with a high capacity for pDNA were sought. Therefore CIM DEAE and Fractogel EMD DEAE with a dynamic binding capacity between 5 and $10 \mathrm{~g}$ pDNA/l support were selected. In both cases the pool from the previous HIC step can be directly used as feed solution for the AIEC. As published by Strancar et al. (2002) and confirmed by our own results for pDNA (Urthaler et al., 2005) the monolithic support is characterized by a flow rate-independent resolution. Furthermore, only a short bed is needed for the separation, which keeps the backpressure at a lower level. To overcome the bottleneck of scalability the approach of radial flow columns and a tube-in-a-tube design were chosen (Podgornik et al., 1999). The high flow rates applicable are the main advantage of the monolithic support over a particulate one. Since also capacity is more or less flow rate-independ- ent, the productivity of the monolith is 5-10 times higher. The CIM DEAE tube monolithic columns of $800 \mathrm{ml}$, as currently the largest commercially available size are suitable for the production of up to 15 $\mathrm{g}$ of purified pDNA. Fractogel EMD DEAE was applied for the production exceeding 10-15 g of purified $\mathrm{pDNA}$.

Independent of the support used the preparative elution profile was similar when both options were compared. Two baseline-separated peaks were observed. The first small peak predominantly contained non-pDNA impurities. The second peak contained the desired supercoiled pDNA product at a high concentration. For the industrial production a step gradient was optimized for the CIM (Urthaler et al., 2005). The collected peak contained pDNA of a further improved purity. Due to the high capacity of the resin and the relatively small elution volume of about 5 column volumes the concentration of the resulting pool was high (up to 10-fold compared to the initial concentration). The homogeneity was maintained during this step. Regarding impurities this step is especially useful for further removal of proteins and endotoxins. The pDNA recovery of over 95\%, without regeneration, was satisfactory. Yields greater than $90 \%$ were usual for AIEC as an intermediate step. The AIEC pool was directly processed by the polishing step.

As the last purification step size exclusion chromatography (SEC) was chosen, since it has the potential to reach two objectives in one operation. On the one hand, a further purification was aspired and on the other, a buffer exchange.
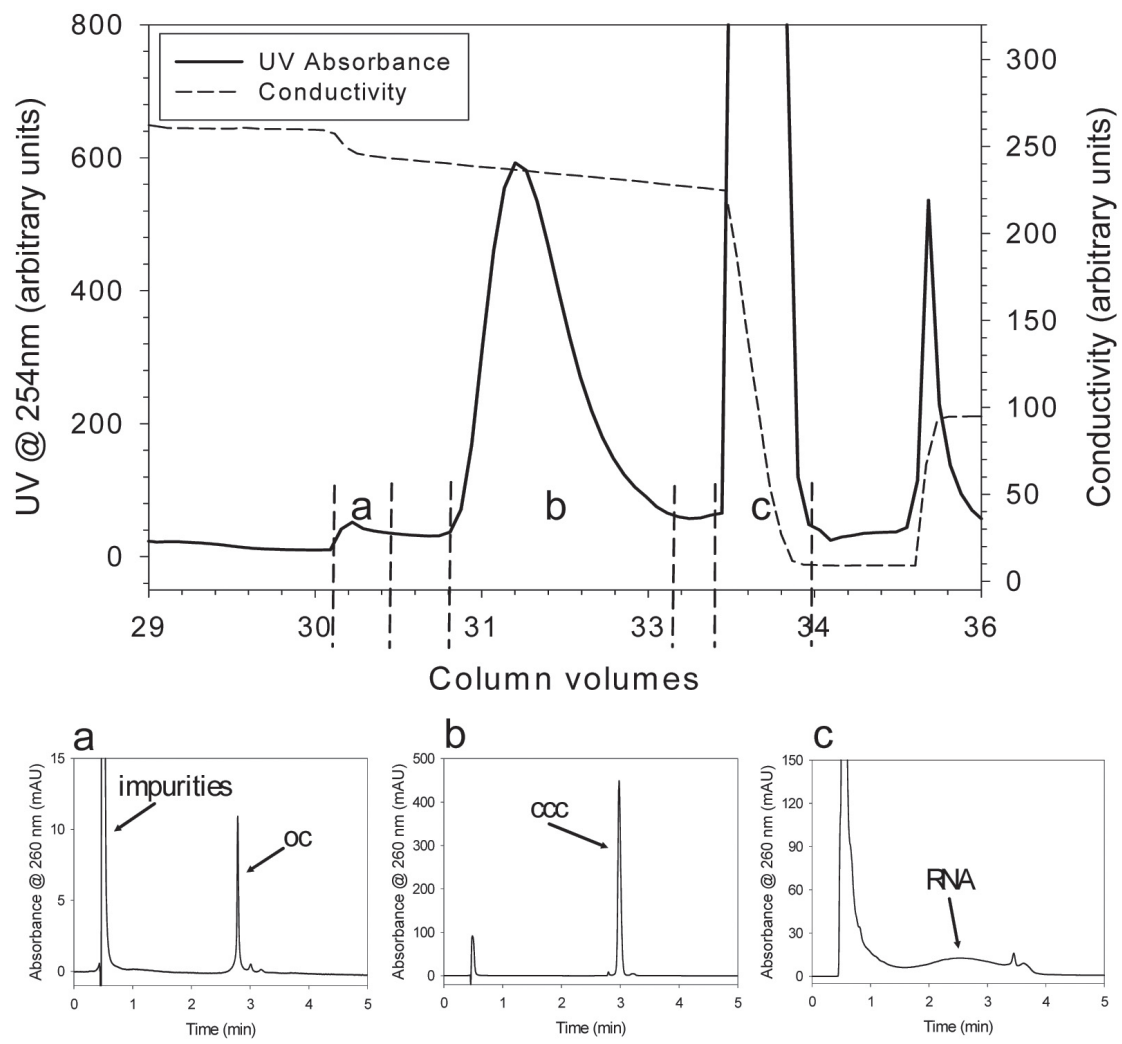

Figure 4. Performance of the HIC step.

Top: Elution profile of the HIC step (pRZ-hMCP1，4.9 kbp). Main fractions are indicated by dashed lines. Bottom: Analytical HPLC chromatograms of the HIC fractions; a) the first HIC peak contains impurities and open circular (oc) pDNA; b) the second HIC peak contains mainly supercoiled (ccc) pDNA; c) residual RNA and further impurities elute when conductivity is suddenly strongly decreased. More strongly bound material is washed out of the column during regeneration (peak at the end of the HIC chromatogram). 
Table 3. Reproducibility and scalability.

Data for drug substance of three consecutive lab-scale runs and three consecutive runs at the industrial scale. All concentration values given per mg pDNA. The values for RNA represent the lowest tested reference concentration. gDNA at the lab scale was determined by Southern blotting (values given represent the lowest tested reference concentration), while at the industrial scale qPCR was used.

\begin{tabular}{llllllll}
\hline Run & $\begin{array}{l}\text { Yield } \\
(\%)\end{array}$ & $\begin{array}{l}\text { Homogeneity } \\
(\% \mathrm{ccc})\end{array}$ & $\begin{array}{l}\text { UV Scan } \\
260 / 280 \mathrm{~nm}\end{array}$ & $\begin{array}{l}\text { RNA } \\
(\mu \mathrm{g} / \mathrm{mg})\end{array}$ & $\begin{array}{l}\text { gDNA } \\
(\mu \mathrm{g} / \mathrm{mg})\end{array}$ & $\begin{array}{l}\text { Protein } \\
(\mu \mathrm{g} / \mathrm{mg})\end{array}$ & $\begin{array}{l}\text { Endotoxin } \\
(\mathrm{EU} / \mathrm{mg})\end{array}$ \\
\hline Lab Scale 1 & 71 & 95 & 1.91 & $<40$ & $<25$ & 0.8 & $0.9-1.8$ \\
Lab Scale 2 & 56 & 96 & 1.92 & $<40$ & $<25$ & 0.6 & $0.2-0.4$ \\
Lab Scale 3 & 68 & 97 & 1.92 & $<40$ & $<25$ & 0.7 & $0.1-0.2$ \\
Industrial Scale 1 & 40 & 95 & 1.93 & $<20$ & 4 & 0.5 & $0.03-0.06$ \\
Industrial Scale 2 & 44 & 96 & 1.92 & $<20$ & 8 & 0.6 & $0.02-0.04$ \\
Industrial Scale 3 & 50 & 96 & 1.94 & $<20$ & 3 & 0.8 & $0.02-0.04$ \\
\hline
\end{tabular}

For the polishing step by SEC a resin with a high maximum feed volume of $30 \%$ of the column volume and a relatively high applicable flow rate of $60 \mathrm{~cm} / \mathrm{h}$ was selected. Separation of undesired pDNA isoforms was not taken into account for the SEC step since the homogeneity of the AIEC pool is usually already at a sufficiently high level. During processing, the large pDNA molecules leave the column within the void volume. Since the salt, present in the feed solution, follows much later, a buffer exchange is possible. It can be assumed that any desired composition, depending on the specific needs for the final formulation, is possible as the mobile phase. Furthermore, residual lower molecular mass impurities, predominantly proteins and endotoxins, observed as the second absorbance peak, can sufficiently be separated. HPLC analysis of the pool did not show any residual impurities. The pDNA recovery was always in the range of $100 \%$. Since polishing by SEC is carried out in a group separation mode and no unspecific binding of pDNA to the column was observed the yield was usually greater than $95 \%$. The fractions at the front and the tail of the product peak containing the residual 5\% were not pooled due to the low concentration.

For the final adjustment of the concentration by ultrafiltration, concentrations between 2 and 5 g/l are typically needed. However, our experiments showed that even $10 \mathrm{~g} / \mathrm{l}$ is possible. Although the pDNA is cycled several times through the pump, the pDNA homogeneity was maintained (>95\%) due to the short process time. Recovery rates of about $95 \%$ without regeneration and yields usually greater than $90 \%$ confirmed the suitability of this process operation. The retentate is finally filtered $(0.22 \mu \mathrm{m})$ with a yield of about $100 \%$.

The purification steps deliver a final high-purity pDNA product of high homogeneity. Reproducibility and scalability of the process was confirmed by comparing the results (drug substance) of ten lab scale and ten industrial scale runs. As an example the results of six respective runs is shown in Table 3. Since all process steps showed an average yield greater than $80 \%$, the resulting overall yield was in the range of $40-70 \%$ and thereby slightly higher for the lab-scale runs. In this regard it has to be considered that yield is also influenced by the initial homogeneity of the pDNA in the cells, which was lower for the industrial scale runs shown. The obtained homogeneity and impurity results meet or even significantly exceed the usual requirements. Especially the endotoxin content was even lower at the industrial scale. By the recovery data and additional verification of the cleaning procedure it could be shown that all supports used are sanitizeable and that batch to batch contamination can therefore be excluded.

\section{DISCUSSION}

The presented process overcomes the challenges of industrial-scale production of $\mathrm{pDNA}$ as a new therapeutic molecule. It combines genetically optimized cell systems and a fed-batch fermentation technique with novel and conventional technologies for the purification. The pDNA produced under GMP conditions is suitable for pharmaceutical applications. By implementing innovative process steps, the bottlenecks of traditional lab-scale processes could be circumvented.

For the lysis a method and a suitable device, which combines the intrinsic cell disintegration step, the neutralization step and the clarification, were developed. As a high-throughput-alternative hollow fiber membranes were used for lysate concentration in order to reduce process time of the subsequent steps. Since a large fraction of impurities are effectively removed by precipitation by ammonium sulfate this step serves as an additional purification step. Chromatographic purification is performed by HIC as a capture step, by AIEC as an intermediate step and SEC as a polishing step. HIC was shown to be the most effective chromatography step regarding separation of oc-pDNA, residual RNA and endotoxins. AIEC provides both further purification and 
some homogeneity increase as well as concentration of the pDNA solution. The application of monolithic supports at this step significantly increased productivity. SEC was used to separate low-molecular-mass impurities and to exchange the buffer to any desired buffer for final formulation. A final optional ultrafiltration step for adjustment of the requested concentration completes the process sequence.

The downstream processing can be carried out within a net process time of less than $24 \mathrm{~h}$ resulting in high-purity pharmaceutical-grade pDNA, meeting all common requirements. Final homogeneities up to $98 \%$ ccc-pDNA are possible at an overall yield of over $50 \%$. Since only standard buffer systems and certified supports and media are used, but no enzymes, no detergents beside SDS during lysis and no organic solvents, the regulatory and safety aspects are also excellent. In addition the developed process was shown to be fully scaleable.

\section{Acknowledgements}

The authors acknowledge the support of the Process Science team of Boehringer Ingelheim Austria $\mathrm{GmbH}$, especially Hans Huber for the fermentation part of the project, Harald Paril for the industrial-scale data, and Franz Kollmann for the process analysis. Special thanks go to Christine Ascher, Helga Wöhrer and Daniel Bucheli for their assistance with the experiments.

\section{REFERENCES}

Asenjo JA, Andrews BA (1990) Enzymatic cell lysis for product release. Bioprocess Technol 9: 143-175.

Bencina M, Podgornik A, Strancar A (2004) Characterization of methacrylate monoliths for purification of DNA molecules. I Sep Sci 27: 801-810.

Birnboim HC, Doly J (1979) A rapid alkaline extraction procedure for screening recombinant plasmid DNA. Nucleic Acids Res 7: 1513-1523.

Birnboim HC (1983) A rapid alkaline extraction method for the isolation of plasmid DNA. Methods Enzymol 100: 243-255.

Branovic K, Forcic D, Ivancic J, Strancar A, Barut M, Gulija TK, Zgorelec R, Mazuran R (2004) Application of short monolithic columns for fast purification of plasmid DNA. J Chromatogr B 801: 331-337.

Carlson A, Signs M, Liermann L (1995) Mechanical disruption of Escherichia coli for plasmid recovery. Biotechnol Bioeng 48: 303-315.

Diogo MM, Queiroz JA, Monteiro GA, Martins SA, Ferreira GN, Prazeres DM (2000) Purification of a cystis fibrosis plasmid vector for gene therapy using hydrophobic interaction chromatography. Biotechnol Bioeng 68: 576-783.

Diogo MM, Queiroz JA, Monteiro GA, Martins SAM, Ferreira GNM, Prazeres DMF (2000) Purification of a cystic fibrosis plasmid vector for gene therapy using hydrophobic interaction chromatography. Biotechnol Bioeng 68: 576-583.
Endres HN, Johnson JA, Ross CA, Welp JK, Etzel MR (2003) Evaluation of an ion-exchange membrane for the purification of plasmid DNA. Biotechnol Appl Biochem 37: 259-266.

Eon-Duval A (2003) Large-scale manufacturing of plasmid DNA for gene therapy and DNA vaccination - Part 1 : The suitability of current techniques to purify plasmid without adding RNase. BioPharm August: 48-57.

Eon-Duval A, Burke G (2004) Purification of pharmaceutical-grade plasmid DNA by anion-exchange chromatography in an RNase-free process. J Chromatogr B 804: 327-335.

Ferreira GNM, Monteiro GA, Prazeres DMF, Cabral JMS (2000) Downstream processing of plasmid DNA for gene therapy and DNA vaccine applications. Trends Biotechnol 18: 380-388.

Foster D (1992) Cell disruption: breaking up is hard to do. Biotechnology (NY) 10: 1539-1541.

Giovannini R, Freitag R, Tennikova TB (1998) High-performance membrane chromatography of supercoiled plasmid DNA. Anal Chem 70: 3348-3354.

Giovannini R, Freitag R'(2002) Continuous isolation of plasmid DNA by annular chromatography. Biotechnol Bioeng 77: 445-454.

Gustavsson PE, Lemmens R, Nyhammar T, Busson P, Larsson PO (2004) Purification of plasmid DNA with a new type of anion-exchange beads having a non-charged surface. J Chromatogr A 1038: 131-140.

Hayashizaki Y (1997) EP Patent 0814156.

Horn NA, Meek JA, Budahazi G, Marquet M (1995) Cancer gene therapy using plasmid DNA: purification of DNA for human clinical trials. Hum Gene Ther 6: 565-573.

Horn N, Budahazi G, Marquet M (1998) WO Patent 98/ 05767.

Jansen J-C, Petterson T (1993) Large scale chromatography of proteins. In Preparative and Production Scale Chromatography. Ganetsos G, Barker PE, eds, pp 559-590. Marcel Dekker, New York.

Kreuzer KN, Cozzarelli NR (1980) Formation and resolution of DNA catenanes by DNA gyrase. Cell 20: 245254.

Lander RJ, Winters M, Meacle F (2001) WO Patent 01/ 46215.

Levy MS, Ciccolini LAS, Yim SS, Tsai JT, Titchener-Hooker N, Shamlou PA, Dunnill P (1999a) The effects of material properties and fluid flow intensity on plasmid DNA recovery during cell lysis. Chem Eng Sci 54: 31713178.

Levy MS, Collins IJ, Yim SS, Ward JM, Titchener-Hooker N, Shamlou PA, Dunnill P (1999b) Effect of shear on plasmid DNA in solution. Bioprocess Biosyst Eng 20: 7-13.

Levy MS, Lotfian P, O'Kennedy R, Lo-Yim MY, Shamlou PA (2000a) Quantitation of supercoiled circular content in plasmid DNA solutions using a fluorescence-based method. Nucleic Acids Res 28: E57.

Levy MS, O'Kennedy RD, Shamlou PA, Dunnhill P (2000b) Biochemical engineering approaches to the challenges of producing pure plasmid DNA. Trends Biotechnol 18: 296-305.

Marquet M, Horn N, Meek J, Budahazi G (1995) WO Patent 95/21250.

Mao QM, Johnston A, Prince IG, Hearn MTW (1991) Predicting the performance of non-porous particles in affinity chromatography. J. Chromatogr A 548: 147-163.

Mao QM, Stockmann R, Prince IG, Hearn MT (1993) Highperformance liquid chromatography of amino acids, peptides and proteins. CXXVI. Modelling of protein adsorption with non-porous and porous particles in a finite bath. J Chromatogr A 646: 67-80. 
Marquet M, Horn NA, Meek JA (1997) Characterization of plasmid DNA vectors for use in human gene therapy. BioPharm May: 42-50.

Martin R (1996) Gel Electrophoresis: Nucleic Acids. Bios Scientific, London.

McNeilly D (1999) WO Patent 99/29832.

Middaugh CR, Evans RK, Mongomery DL, Casimiro DR (1998) Analysis of plasmid DNA from a pharmaceutical perspective. J Pharm Sci 87: 130-146.

Miller H (1987) Practical aspects of preparing phage and plasmid DNA: Growth, maintenance, and storage of bacteria and bacteriophage. Methods Enzymol 152: 145 170.

Murphy JC, Jewell DL, White KI, Fox GE, Willson RC (2003) Nucleic acid separations utilizing immobilized metal affinity chromatography. Biotechnol Prog 19: 982986.

Necina R, Urthaler J, Strancar A, Jancar J, Merhar M, Barut M, Podgornik A (2003) WO Patent 03/051483.

Podgornik A, Barut M, Strancar A, Josic D (1999) WO Patent 99/44053.

Prather KJ, Sagar S, Murphy J, Chartrain M (2003) Industrial scale production of plasmid DNA for vaccine and gene therapy: Plasmid design, production and purification. Enzyme Microb Technol 33: 865-883.

Prazeres DM, Schluep T, Cooney C (1998) Preparative purification of supercoiled plasmid DNA using anion-exchange chromatography. J Chromatogr A 806: 31-45.

Prazeres DMF, Ferreira GNM, Monteiro GA, Cooney CL, Cabral JMS (1999) Large-scale production of pharmaceutical-grade plasmid DNA for gene therapy: problems and bottlenecks. Trends Biotechnol 17: 169-174.

Ribeiro SC, Monteiro GA, Cabral JM, Prazeres DM (2002) Isolation of plasmid DNA from cell lysates by aqueous two-phase systems. Biotechnol Bioeng 78: 376-384.

Schleef M (1999) Issues of large scale plasmid DNA manufacturing. In Biotechnology, 2nd edn vol 5a. Recombinant Proteins, Monoclonal Antibodies and Therapeutic Genes. Rehm HJ, Reed G, Pühler A, Stadler P, eds, pp 443469. Wiley- $\mathrm{VCH}$, Weinheim.

Schluep T, Cooney CL (1998) Purification of plasmids by triplex affinity interaction. Nucleic Acids Res 26: 45244528.

Shamlou PA (2003) Scaleable processes for the manufacture of therapeutic quantities of plasmid DNA. Biotechnol Appl Biochem 37: 207-218.

Sinden RR, Alkek AB (1994) DNA Structure and Function. pp 95-133. Academic Press, San Diego.

Sofer G, Hagel L (1997a) Escherichia coli, The purification strategy, Chromatography. In Handbook of Process Chromatography, A Guide to Optimization, Scale-up, and Validation, pp 10-12, 43-54, 132-172. Academic Press, London.

Sofer G, Hagel L (1997a) Optimization goals. In Handbook of Process Chromatography, A Guide to Optimization, Scaleup, and Validation, pp 54-58. Academic Press, London.
Strancar A, Podgornik A, Barut M, Necina R (2002) Short monolithic columns as stationary phases for biochromatography. In Advances in Biochemical Engineering/Biotechnology, vol 76, Scheper T, ed, pp 49-85. Springer Verlag, Berlin.

Strick TR, Allemand J-F, Bensimon D, Croquette V (1998) Behavior of supercoiled DNA. Biophys J 74: 2016-2028.

Summers DK (1996) The Biology of Plasmids. Blackwell Science, Oxford.

Svec F, Frechet JMJ (1995) Modified poly(glycidyl methacrylate-co-ethylene dimethacrylate) continuous rod columns for preparative-scale ion-exchange chromatography of proteins. J Chromatogr A 702: 89-95.

Tennikova TB, Svec F (1993) High performance membrane chromatography: highly efficient separation method for proteins in ion-exchange, hydrophobic interaction and reversed-phase modes. J Chromatogr A 646: 279-288.

US FDA (1996a) Points to Consider on Plasmid DNA Vaccines for Preventive Invectious Disease Indications, US Food and Drug Administration, Rockville, MD.

US FDA (1996b) Addendum to The Points to Consider in Human Somatic Cell and Gene Therapy, US Food and Drug Administration, Rockville, MD.

US FDA (1996c) Addendum to The Points to Consider in Human Somatic Cell and Gene Therapy. Hum Gene Ther 7: 1181-1190.

US FDA (1998) Guidance for Industry: Guidance for Human Somatic Cell Therapy and Gene Therapy, US Food and Drug Administration, Rockville, MD.

Urthaler J, Necina R, Ascher C, Wöhrer H (2004) WO Patent 2004/085643.

Urthaler J, Schlegl R, Podgornik A, Strancar A, Jungbauer A, Necina R (2005) Application of monoliths for plasmid DNA purification-development and transfer to production. J Chromatogr A 1065: 93-106.

Weir N (1999) Non-viral vectors for gene therapy. In Biotechology, Mountain A, Ney UM, Schomburg D, eds, vol 5a, pp 427-441. Wiley-VCH, Weinheim.

Wicks IP, Howell ML, Hancock T (1995) Bacterial lipopolysaccharide copurifies with plasmid DNA: implications for animal models and human gene therapy. Hum Gene Ther 6: 317-323.

Varley DL, Hitchcock AG, Weiss AM, Horler WA, Cowell R, Peddie L, Sharpe GS, Thatcher DR, Hanak JA (1999) Production of plasmid DNA for human gene therapy using modified alkaline cell lysis and expanded bed anion exchange chromatography. Bioseparation 8: 209217.

Zhang S, Krivosheyeva A, Nochumson S (2003) Largesscale capture and partial purification of plasmid DNA using anion-exchange membrane capsules. Biotechnol Appl Biochem 37: 245-249.

Zöchling A, Hahn R, Ahrer K, Urthaler J, Jungbauer A (2004) Mass transfer characteristics of plasmids in monoliths. J Sep Sci: 27: 819-827. 